\title{
Pharmacognostic Studies of the Leaves, Stem and Root of Capparis erythrocarpos Isert (Capparaceae)
}

\author{
Twumasi Mary A', Ekuadzi Edmund ${ }^{1} *$, Mante Priscilla K², Boakye-Gyasi Mariam E , Mensah Merlin LK ${ }^{4}$, Woode Eric ${ }^{2}$
}

\section{Twumasi Mary A' ${ }^{1}$, Ekuadzi Edmund ${ }^{1, *}$, Mante Priscilla $\mathrm{K}^{2}$, Boakye-Gyasi Mariam $\mathrm{E}^{3}$, Mensah Merlin LK ${ }^{4}$, Woode Eric ${ }^{2}$}

'Department of Pharmacognosy, Faculty of Pharmacy and Pharmaceutical Sciences, Kwame Nkrumah University of Science and Technology,

Kumasi, GHANA.

${ }^{2}$ Department of Pharmacology, Faculty of Pharmacy and Pharmaceutical Sciences, Kwame Nkrumah University of Science and Technology, Kumasi, GHANA.

${ }^{3}$ Department of Pharmaceutics, Faculty of Pharmacy and Pharmaceutical Sciences, Kwame Nkrumah University of Science and Technology, Kumasi, GHANA.

${ }^{4}$ Department of Herbal Medicine, Faculty of Pharmacy and Pharmaceutical Sciences, Kwame Nkrumah University of Science and Technology, Kumasi, Ghana.

Correspondence

Dr. Ekuadzi Edmund

Department of Pharmacognosy, Faculty of Pharmacy and Pharmaceutical Sciences, Kwame Nkrumah University of Science and Technology, Kumasi, GHANA.

Phone no : +23326 6175663

E-mail: eekuadzi.pharm@knust.edu.gh

History

- Submission Date: 27-07-2018;

- Review completed: 04-10-2018;

- Accepted Date: 15-11-2018

DOI : 10.5530/pj.2019.1.19

Article Available online

http://www.phcogj.com/v11/i1

Copyright

() 2019 Phcog.Net. This is an openaccess article distributed under the terms of the Creative Commons Attribution 4.0 International license.

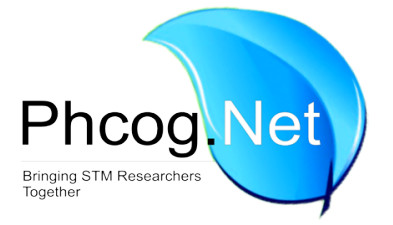

ABSTRACT

Introduction: The roots of Capparis erythrocarpos are used traditionally across Africa for the management of pain, arthritis and other forms of inflammatory conditions. Owing to its proven efficacy, it has gained commercial value, particularly as a key ingredient in several herbal products and alcoholic beverages. The increased scarcity owing to demand outstripping supply lend the roots of $C$. erythrocarpos to adulteration. This paper presents a detailed pharmacognostic evaluation of the leaf, stem and root of $C$. erythrocarpos which will be used in its identification and consequent standardization. Methods: The leaf, stem and root were evaluated for their macroscopic and microscopic features as were the physicochemical parameters and phytochemical screening done. Results: Leaves are alternately arranged, have collateral vascular bundle, crystal sheaths and a pericyclic fibre. Actinocytic stomata and secretory cells were contained in powdered leaves. The stem showed lenticels and thorns, stellate and branched trichomes which leave off cicatrices in older stems. The powdered stem and roots contained stone cells, secretory cells and scalariform vessels. However, the roots lacked thorns, trichomes and had smaller secretory cells. Aqueous and ethanolic extracts of the leaves, stem and roots were slightly acidic to neutral. Ash values of leaves, stem and roots are $(16.58 \pm 0.09) \% \mathrm{w} / \mathrm{w},(5.01 \pm 0.09) \% \mathrm{w} / \mathrm{w}$ and $(6.53 \pm 0.19) \% \mathrm{w} / \mathrm{w}$ respectively. Preliminary phytochemical screening of the leaves, stem and roots showed the presence of glycosides, flavonoids and tannins. Conclusion: The determined parameters for the leaf, stem and root of $C$. erythrocarpos constitute quality parameters for their unequivocal identification.

Key words: Capers, crystal sheaths, Cicatrices, physicochemical parameters, Morphological features, Herbal medicine.

\section{INTRODUCTION}

Natural products hold potential sources of novel compounds with varied bioactivities. Bioactivity studies should be preceded with a clear cut standardization of the plant to avoid intentional or non-intentional adulteration as this can lead to treatment failure, sub therapeutic effect or even death. Capparis erythrocarpos, an important medicinal plant in herbal medicine used globally in the management of pain and other inflammatory conditions lack standards for quality control.

Globally, there are about 650 species present in the family and 250 species present in the genus Capparis. Though such a huge number globally, just a few of them are found locally. ${ }^{1}$ In Ghana, five species have been identified. ${ }^{1-2}$ Among these species, C. erythrocarpos, commonly referred to as capers ${ }^{3}$ has been found to be the most commonly used for the management of several ailments. A mention of the plant in Ayurveda states the use of the stem bark and root for its analgesic and other inflammatory disorders. ${ }^{4}$ Across Africa, the roots are used for the treatment of conjunctivitis, headache $^{5}$ and chronic diarrhoea. ${ }^{6}$ In Tanzania, capers is used in the management of child convulsive fever and inflammation of the connective tissue of the eye. ${ }^{7}$ In Uganda, the whole shrub is used for the management of menstrual pains, infertility and anemia. ${ }^{8}$ In Ethiopia, it is used traditionally for the management of symptoms of cyst and skin infections. In Kenya, it is used as an antidiarrheal and anthelmintic agent. ${ }^{4}$ In Ghana, it is used for the management of pain, arthritis and other forms of inflammatory conditions. ${ }^{5}$ Pharmacological investigations have been conducted on C. erythrocarpos and it possesses anti-arthritic effects $^{7-10}$ without any organ specific toxic effects. ${ }^{11}$ Phytochemical analysis of the ethanol extract of C. erythrocarpos root revealed the presence of alkaloids and flavonoids. ${ }^{9}$

In Ghana, Capparis erythrocarpos roots and its formulations are in high demand commercially. It is used by Kasapreko Group of Companies for their Alomo bitters brand variants which have received global acclaim ${ }^{12}$ and is marketed as an alcoholic beverage and appetite stimulant. The Centre for Plant Medicine Research (CPMR) uses the root in 
an oral formulation, Sirrapac, as an antiarthritic medication. ${ }^{11}$ Due to their popularity and high value, C. erythrocarpos containing products are a target for economically driven adulteration. In the face of demand outstripping supply and the economic motives for adulteration being considerable, Capparis erythrocarpos is at risk of an admixture or complete substitution with closely related species. This is made worse, by the use of the roots (which requires the destruction of the whole plant). A study in 2007 highlighted the unnoticed threatened state of C. erythrocarpos and the need for its sustainable use and conservation. ${ }^{13}$

Despite its wide use and potential for adulteration, no report exists of a pharmacognostic study aimed at unequivocally identifying C. erythrocarpos from its closely related species. Authentication of C. erythrocarpos is of primary importance for both consumers and the industries that manufacture products containing C. erythrocarpos. For the industries, product authentication is essential to maintain trust of consumers and avoid unfair competition that can eventually create a destabilized market and disrupt regional or national economies. Consumers also will have the full benefit of quality products that promote their health and well-being. Clearly, a study that addresses this gap in knowledge holds numerous benefits for the herbal medicine industry.

Consequently, this paper aims at establishing quality standards for the unequivocal identification of Capparis erythrocarpos. The macro- and micro morphological features, physicochemical properties and fluorescence characteristics were determined using standard methods.

\section{MATERIALS AND METHODS}

\section{Materials}

Reagents and chemicals of analytical grade were purchased from Sigma Aldrich Co. Ltd. A Leica DM. 700 light microscope fitted with camera (Leica ICC50 HD) was used for all the microscopy. Fluorescence analysis was performed with UVGL58 UV lamp (Cambridge, UK).

\section{Plant Collection and Authentication}

Leaves, stem and roots of Capparis erythrocarpos were collected from Ayikuma, Ghana (555'2.384”N, 00'40.3092”W). Parts collected were authenticated by Dr. George Henry Sam of the Department of Herbal Medicine.

Leaf samples were pressed while the stem and root samples were stored in formaldehyde (37\%) solution. They were deposited at the herbarium of the Herbal Medicine Department, Faculty of Pharmacy and Pharmaceutical Sciences (FPPS), Kwame Nkrumah University of Science and Technology (KNUST) with the identification codes KNUST/HM1/2017/ L002, KNUST/HM1/2017/S012 and KNUST/HM1/2017/R004 for leaf, stem and root respectively.

\section{Methods}

\section{Macromorphology and micromorphology of leaf}

The color, taste, odor and texture of the leaves of Capparis erythrocarpos were determined and recorded as per standard procedures. ${ }^{14}$

The leaves of C. erythrocarpos were macro-morphologically characterized. ${ }^{14}$ For histological studies, the transverse and longitudinal sections of the leaf midrib were prepared and stained as per standard procedures. ${ }^{14-15}$

Powdered leaves was mounted in appropriate reagents. Cell contents and inclusions were described by standard procedures. ${ }^{14-16}$

Quantitative evaluations (stomatal number, stomatal index, palisade ratio, vein-islet number and veinlet termination numbers) and measurements were done. Area measurements and particle counting were achieved using Image J (National Institute of Health, USA, http://imagejnih.gov/ij) and Microsoft Excel, Microsoft Office Professional Plus 2013.

\section{Macromorphology and micromorphology of stem}

Similar standard procedures were performed as described for leaves. Quantitative evaluations were however not performed. Powdered stem was mounted in appropriate reagents and observed under the microscope.

\section{Macromorphology and micromorphology of roots}

Similar standard procedures were performed as described for the leaves. Powdered roots was mounted in appropriate reagents and observed under the microscope. Quantitative evaluations were not performed.

\section{Physicochemical and phytochemical characters}

Physicochemical parameters, extractive and ash values determinations as well as phytochemical screening of powdered samples were performed by standard procedures. ${ }^{14-15}$ Test samples were run in triplicates.

\section{Fluorescence analysis}

The leaves, stem and root powders were observed for characteristic colors. Strong acids, alkalis and organic solvents were added and thereafter observed under the visible, short $(254 \mathrm{~nm})$ and long wavelengths $(366 \mathrm{~nm})$.

\section{Plant extraction}

The method of extraction was carried out as per the protocol employed by Centre for Plant Medicine Research (CPMR), Akuapim-Mampong, Eastern Region. Plant material (roots, stem and leaves) was warm macerated in water for three hours. It was filtered, concentrated under low temperature $\left(40^{\circ} \mathrm{C}\right)$ for $6 \mathrm{~h}$ and freeze dried to obtain a powdery mass. The yield obtained for the roots, stem and leaves were $0.79 \%, 0.59$ $\%$ and $2.73 \%$ respectively.

\section{Fourier Transform Infrared (FTIR) fingerprint}

The spectra of the extracts were measured as a solid film using a PerkinElmer Spectrum Two Universal Attenuated Total Reflectance (UATR) FTIR spectrometer. They were recorded with 32 scans at a resolution of $4 \mathrm{~cm}^{-1}$ over a wavenumber range of $4000-400 \mathrm{~cm}^{-1}$.

\section{RESULTS}

\section{Macromorphology and micromorphology of leaf}

The fresh matured leaves were green colored, elliptical to ovate shaped, bitter to taste and musty in odour. The simple leaves were alternately arranged with pinnate venation, sinuate margin, acute apex, short stalked petiole and has two spiny stipules on the symmetrical base (Figure 1A). They are fleshy and have a glossy appearance. The striking difference between the young and old leaves is the light green lanceolate shaped young leaves $(4.2 \times 0.8) \mathrm{cm}$ (Figure $1 \mathbf{A})$ as opposed to dark green elliptical to ovate old leaves $(7.6 \times 3.8) \mathrm{cm}$.

The transverse section of the midrib of C. erythrocarpos young leaf showed a simple arrangement consisting of a layer of upper and lower epidermal cells each respectively overlaid with a thick cuticle. The abaxial surface had no palisade cells (Figure 2A). Dispersed in the collenchyma and parenchyma cells are crystal sheaths and starch grains. Also present was an arc- shaped unicollateral vascular bundle (Figure 2A). The lamina showed wavy epidermal cells with stomata scattered in them. Attached to the lamina were branched and stellate trichomes (Figure 3). Worth noting is the more advanced cellular structures: higher degree of lignification and pericyclic fibers (Figure 2B) in the older leaf. Also present in the older leaves were branched and/or unicellular clothing trichomes. In the section of the young and old leaves, dark blue stained starch grains and pink lignified xylem vessels were observed. Safranin stained the cuticle bright red and the lignified pericyclic vessel purplish violet (Figure 2B). 

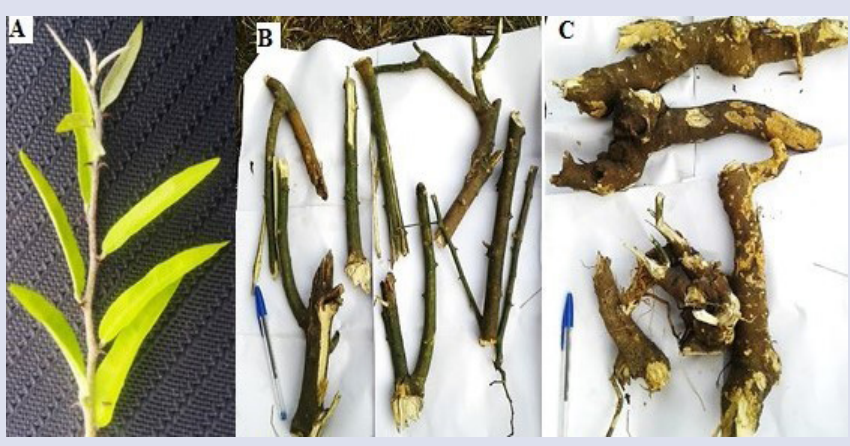

Figure 1: A-Leaves $(X 0.7)$ showing alternate arrangement, B-stem-showing thorns (X 0.1) and C- roots (0.3) of Capparis erythrocarpos; Leaves, stem and root of Capparis erythrocarpos

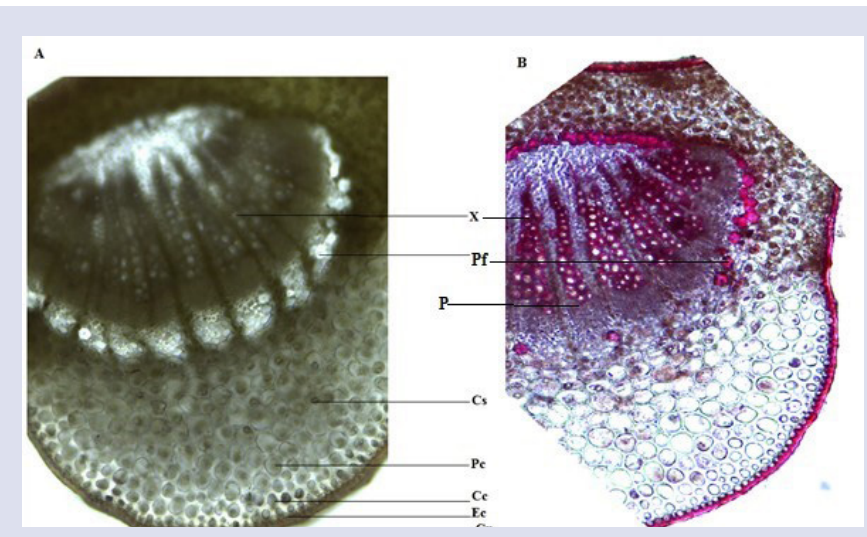

Figure 2: Transverse section of the midrib of a leaf of $C$. erythrocarpos showing $A(X 400)$ : section with $\mathrm{Cu}=$ cuticle, $\mathrm{Ec}=$ epidermal cell, $\mathrm{Cs}=\mathrm{Crystal}$ sheath, $\mathrm{Cc}=$ collenchyma cell, $\mathrm{Pc}=$ Parenchyma cell, $\mathrm{X}=\mathrm{Xylem}, \mathrm{P}=\mathrm{Phloem}$, $\mathrm{Pf}=$ Pericyclic fiber, $\mathrm{B}(\mathrm{X} 400)=$ Safranin stained section; Midrib of leaf of $C$. erythrocarpos

Powdered leaves have prismatic calcium oxalate crystals, crystal sheaths, stomata with straight to wavy walled epidermal cells, unicellular and branched trichomes, secretory cells, lignified vessels and fibers.

\section{Leaf surface data determinations}

Epidermal cells on both surfaces of C. erythrocarpos leaf are slightly wavy walled. C. erythrocarpos has a palisade ratio of 6 . The main type of stomata present on both surfaces is the anomocytic stomata. Other types of stomata present include anisocytic and actinocytic. The leaf is amphistomatic with the adaxial surface bearing a lower number (12.4 to 29.7 to 49.5) than the abaxial surface ( 24.8 to $\mathbf{4 2 . 1}$ to 49.5 ). The stomatal index ranges for the adaxial and the abaxial surfaces are 4.8 to $\mathbf{1 4 . 2}$ to 25.0 and 11.1 to $\mathbf{1 5 . 5}$ to 25.0 respectively. The stomata is $0.018 \pm 0.004 \mathrm{~mm}$ long and $0.019 \pm 0.003 \mathrm{~mm}$ wide.

The vein-islet number and the veinlet terminations were 3.96 to 4.46 and 1.86 to 3.47 respectively. The vein islets are polygonal and the vein islet terminations are fork shaped (Figure 3).

\section{Macromorphology and micromorphology of stem}

The woody stem of C. erythrocarpos organoleptically assessed has bitter taste and a musty odor. The young stems are green, old stems are greenish brown (Figure 1B) and the inner parts are creamish white. The stem showed white patches, lenticels and wrinkles which were well distributed all over the outer bark. The pattern of fracture is splintery and it assumes a channeled curvature.

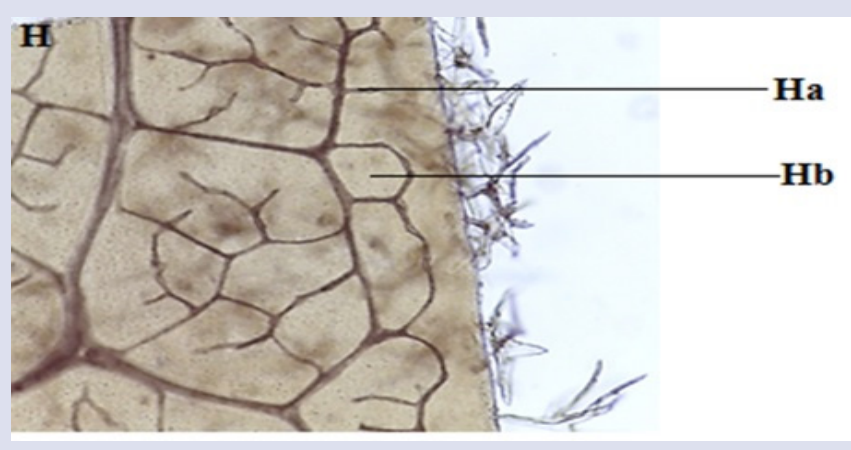

Figure 3: Whole leaf of C. erythrocarpos (X 100) showing Ha=vein Islet terminations $\mathrm{Hb}=$ Vein islets; Whole leaf of $\mathrm{C}$. erythrocarpos

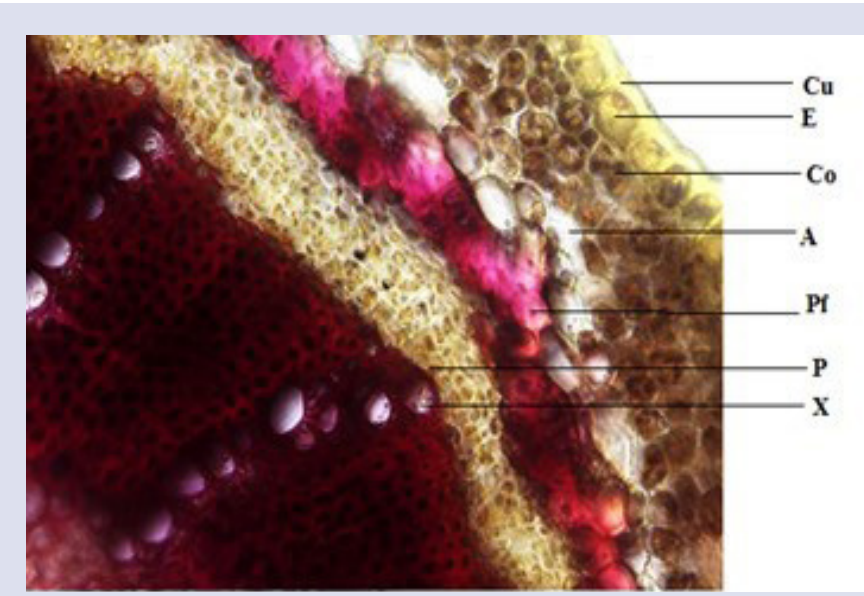

Figure 4: Transverse section of the stem (X 100) showing $\mathrm{Cu}=$ cuticle, $\mathrm{E}=$ epidermal cell, $\mathrm{Co}=$ collenchyma, $\mathrm{A}=$ aerenchyma, $\mathrm{Pf}=$ pericyclic fibre, $\mathrm{P}=$ phloem, $\mathrm{X}=\mathrm{xylem}$; Transverse section of stem.

A transverse section of the stem of C. erythrocarpos reveals a lot of branched and stellate trichomes attached to a thick layer of cuticle. Sections from older stems have cicatrices (stumps from broken trichomes). Present was a single layer of epidermal cells (Figure 4), isodiametric parenchyma cells and a pith containing prismatic calcium oxalate crystals and numerous starch grains. The vascular bundle has lignified vessels with outer phloem (Figure 4).

The powdered stem contains a lot of starch grains, numerous vessels and lignified sclerenchymatous cells.

\section{Macromorphology and microscopy of root}

The root of C. erythrocarpos has bitter taste. Macromorphological features of the root are similar to the stem (Figure 1C).

The root has one to two layer(s) of epidermal cells overlaid with a cork with no trichome and four to seven layers of cortical collenchyma cells. Highly dispersed through the isodiametric parenchyma cells are large starch grains and stone cells. Present is a collateral vascular bundle and lignified medullary rays consisting of 15-25 rows of parenchyma cells (Figure 5). In the middle lies a pith. All throughout the cells in the section (from the epidermis to the pith) are oil deposits (Figure 5).

The powdered root showed similar structures as the stem but it lacked trichomes and had smaller secretory cells. 


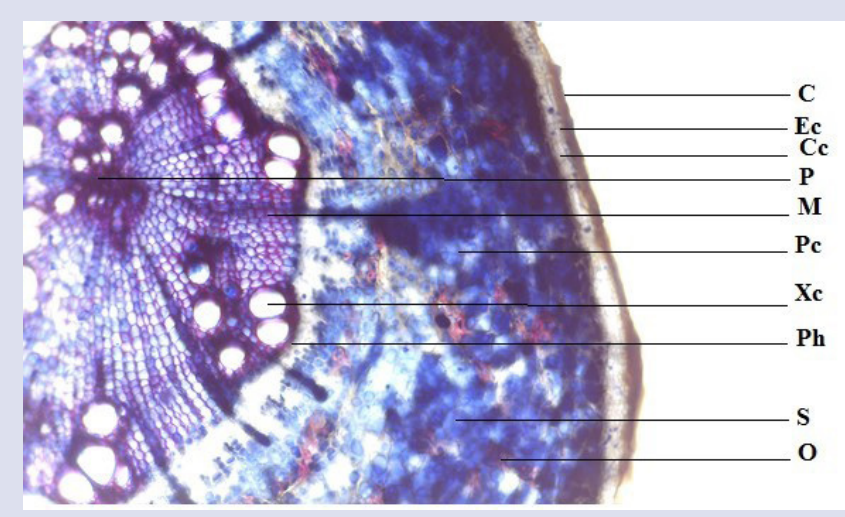

Figure 5: Transverse section of $\operatorname{root}(\mathrm{X} 100)$ showing $\mathrm{C}=\mathrm{cork}$, $\mathrm{Ec}=$ =pidermal cell, $\mathrm{Cc}=$ collenchyma cell, $\mathrm{P}=$ = pith, $\mathrm{M}=$ Medullary ray, $\mathrm{Pc}=$ parenchyma cell, $\mathrm{Xc}=$ Xylem cell, $\mathrm{Ph}=$ phloem, $\mathrm{S}=$ starch grain.

Table 1: Physicochemical analysis of the leaves, stem and root of $C$. erythrocarpos $(\mathrm{n}=3)$.

\begin{tabular}{cccc}
$\begin{array}{c}\text { Physical } \\
\text { parameters }\end{array}$ & $\begin{array}{c}\text { Total ash value } \\
(\% \mathrm{w} / \mathrm{w})\end{array}$ & $\begin{array}{c}\text { Acid insoluble ash } \\
\text { value }(\% \mathrm{w} / \mathrm{w})\end{array}$ & $\begin{array}{c}\text { Water soluble ash } \\
\text { value }(\% \mathrm{w} / \mathrm{w})\end{array}$ \\
\hline Leaves & $16.58 \pm 0.09$ & $2.26 \pm 0.03$ & $10.91 \pm 2.92$ \\
Stem & $5.01 \pm 0.09$ & $1.68 \pm 0.40$ & $2.39 \pm 0.93$ \\
Roots & $6.53 \pm 0.19$ & $2.30 \pm 0.88$ & $2.22 \pm 1.34$ \\
\hline
\end{tabular}

Table 2: $\mathrm{pH}$ readings and extractive values of alcohol and water extracts of C. erythrocarpos $(n=3)$.

\begin{tabular}{ccccc}
\hline Plant sample & \multicolumn{2}{c}{ pH Reading } & \multicolumn{2}{c}{ Extractive value $(\% \mathrm{w} / \mathrm{w})$} \\
\hline & Alcohol & Water & Alcohol $(90 \%)$ & Water \\
\hline Leaves & $6.54 \pm 0.04$ & $5.84 \pm 0.05$ & $29.86 \pm 0.04$ & $54.78 \pm 0.06$ \\
Stem & $6.17 \pm 0.06$ & $5.44 \pm 0.05$ & $9.5 \pm 0.04$ & $10.82 \pm 0.05$ \\
Root & $6.3 \pm 0.05$ & $4.55 \pm 0.05$ & $18.3 \pm 0.04$ & $36.80 \pm 0.05$ \\
\hline
\end{tabular}

\section{Physicochemical principles}

Results on ash values have been presented in Table 1 while that of extractive values and $\mathrm{pH}$ readings have been presented in Table 2 .

\section{Phytochemical Screening}

Saponins, tannins, glycosides, flavonols, triterpenoids, coumarins and alkaloids were detected in the powdered leaves, stem and roots of C. erythrocarpos.

\section{Characteristic fluorescence of C. erythrocarpos}

This result is as presented in Table 3.

\section{Fourier Transform Infrared fingerprint (FTIR)}

The FTIR spectra of the leaf, stem and roots extracts of C. erythrocarpos has been presented in Figure 6.

\section{DISCUSSION}

This paper focused on filling the gap in knowledge of standards that guides the correct collection and quality control of C. erythrocarpos parts.
Table 3: Characteristic fluorescence of the leaves, stem and root powders in dry state and different reagents under visible light, long, short wavelengths.

\begin{tabular}{|c|c|c|c|}
\hline Powder & Visible light & $\begin{array}{c}\text { Long } \\
\text { wavelength }\end{array}$ & $\begin{array}{c}\text { Short } \\
\text { wavelength }\end{array}$ \\
\hline Leaves & Green & Light green & No fluorescence \\
\hline Stem & Light green & Light Green & No fluorescence \\
\hline Root & Cream & Light Green & No fluorescence \\
\hline \multicolumn{4}{|c|}{ Powder+ Methanol } \\
\hline Leaves & Green & Light yellow & No fluorescence \\
\hline Stem & Green & Light yellow & No fluorescence \\
\hline Root & Cream & White & Cream \\
\hline \multicolumn{4}{|c|}{$\begin{array}{c}\text { Powder+ } \\
\text { Petroleum ether }\end{array}$} \\
\hline Leaves & Green & Light brown & No fluorescence \\
\hline Stem & Light green & Cream & No fluorescence \\
\hline Root & Cream & Light blue & Light brown \\
\hline \multicolumn{4}{|c|}{ Powder+ $50 \% \mathrm{HCl}$} \\
\hline Leaves & Green & No fluorescence & No fluorescence \\
\hline Stem & Light green & No fluorescence & No fluorescence \\
\hline Root & Cream & Light green & No fluorescence \\
\hline \multicolumn{4}{|c|}{$\begin{array}{c}\text { Powder+ } 50 \% \\
\mathrm{H}_{2} \mathrm{SO}_{4}\end{array}$} \\
\hline Leaves & Green & No fluorescence & No fluorescence \\
\hline Stem & Light green & Brown & No fluorescence \\
\hline Root & Cream & Light green & No fluorescence \\
\hline \multicolumn{4}{|c|}{ Powder $+\mathrm{KOH}$} \\
\hline Leaves & Brown & Light yellow & No fluorescence \\
\hline Stem & Yellow & Light yellow & No fluorescence \\
\hline Root & Light green & Light green & No fluorescence \\
\hline
\end{tabular}

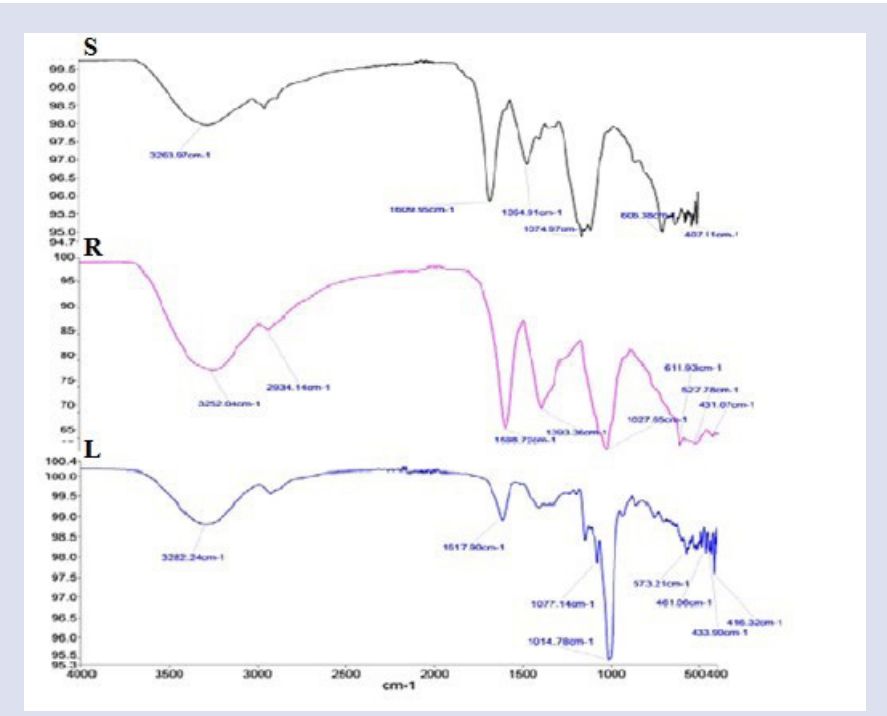

Figure 6: FT-IR fingerprints of the $S$ (stem), R (roots) and L (leaves) of $C$. erythrocarpos showing different stretches of characteristic functional groups and unique fingerprint. Fingerprints of $C$. erythrocarpos. 


\section{Macromorphology and micromorphology of leaf}

Leaf dimensions of C. erythrocarpos are macroscopically similar to those of another member in the genus; Capparis zeylanica. However, C. zeylanica leaves have a rounded base and a mucronate apex. ${ }^{17} \mathrm{C}$. erythrocarpos has small amphistomatic leaves ${ }^{18-19}$ which shorten travel distance of carbon dioxide to mesophyll cells in the leaves. ${ }^{20}$ This enhances photosynthesis in Capparis erythrocarpos. ${ }^{21-22}$ Thick outer epidermal walls, a feature of xerophytes which was confirmed in C. erythrocarpos ${ }^{23-26}$ protects it against drought. ${ }^{26}$ These observed features are essential for easy identification and authentication of the plant.

Safranin, a stain for detecting different types of cells; lignified, cutinized or suberized cell wall ${ }^{25}$ confirmed the presence of lignin and suberin in C. erythrocarpos leaves.

\section{Leaf surface data determinations}

The stomata of C. erythrocarpos is shorter $(0.018 \pm 0.004 \mathrm{~mm})$ but broader $(0.019 \pm 0.003 \mathrm{~mm})$ than another member of the genus, C. spinosa (0.028mm long, $0.010 \mathrm{~mm}$ wide). ${ }^{26}$ Another distinctive feature about C. erythrocarpos leaves is its hyperstomata. Stomatal index, a distinct feature which shows less variability for a given species over stomatal number was determined to aid in C. erythrocarpos' identification. ${ }^{14}$ The ratio of stomatal number on the adaxial and abaxial surfaces was determined since it is of diagnostic importance. ${ }^{14}$ The presence of different types of stomata in C. erythrocarpos is essential for unique physiological regulation of water as these stomatal types respond appropriately to changing climatic conditions. ${ }^{27}$

The vein-islet number and the veinlet termination values were determined as part of identification parameters of C. erythrocarpos..$^{14}$ Polygonal shaped vein islets and the fork shaped vein islet terminations seen for C. erythrocarpos are similar to those observed in C. sepieria. ${ }^{24}$

\section{Macromorphology and micromorphology of stem}

C. erythrocarpos stem, similar to C. spinosa possesses thorns. ${ }^{3,23}$ Also, comparable to C. sepieria, it has thick fibre, vessels arranged within the collateral vascular bundle and small, compact parenchymatous cells. ${ }^{24}$ Similar to C. erythrocarpos, $C$ spinosa has cortical sclereids but not pericyclic fibres. ${ }^{24}$

Numerous starch grains in stem serves as energy reserves for the plant in adverse weather conditions. ${ }^{28}$

\section{Macromorphology and microscopy of root}

The observed features are essential for easy identification and authentication of the plant.

The powdered root has smaller secretory cells as compared to the stem.

\section{Physicochemical principles}

Ash values of C. erythrocarpos (Table 1) are essential in determination of quality; which focuses on grade, presence of earthy matter and purity of drug. ${ }^{29} \mathrm{pH}$ readings of water and alcohol extracts are weakly acidic to neutral (4.0 - 6.54) (Table 2). Extractive values are useful in crude drug evaluation. Values are useful as quality parameters and detection of adulteration in a claimed $C$. erythrocarpos sample. Physicochemical characterization revealed that water extraction gave a better yield as compared to ethanol (Table 2).

\section{Examination of Phytochemical Constituents}

Secondary metabolites present agrees with documented literature of members of this genus and species, C. erythrocarpos. ${ }^{10,30}$ Capparis erythrocarpos have been reported to possess analgesic, anti-inflammatory, antimicrobial, anthelminthic and hepatoprotective properties. ${ }^{31}$ This is mainly due to the secondary metabolites present.

\section{Characteristic fluorescence of C. erythrocarpos}

Characteristic color produced due to the presence of fluorochromes can be used in characterization and subsequent evaluation of crude drug samples (Table 3 ).

\section{Fourier Transform Infrared Fingerprinting}

Fourier transform Infrared was done to obtain fingerprint for quality control of leaves, stem and roots of C. erythrocarpos. Figure 6 reveals unique fingerprints which could be used as reference standard in the authentication of the leaf, stem and root of C. erythrocarpos.

\section{CONCLUSION}

This research work has laid down morphological and physicochemical standards that can be used in the quality control of the leaves, stems and roots of C. erythrocarpos.

\section{ACKNOWLEDGEMENT}

Staff of Central Lab and Department of Pharmacognosy all of Kwame Nkrumah University of Science and Technology. Staff of Mampong Centre for Plant Medicine Research (especially Mrs. Doris Kumador and Mr. Theophilus K. Batsa).

\section{CONFLICT OF INTEREST}

The authors declare no conflict of interest.

\section{ABBREVIATIONS}

CPMR: Centre for Plant Medicine Research; FTIR: Fourier transform Infrared; FPPS: Faculty of Pharmacy and Pharmaceutical Sciences; KNUST: Kwame Nkrumah University of Science and Technology; UATR: Universal Attenuated Total reflectance; UV: Ultraviolet.

\section{REFERENCES}

1. Quattrocchi U. CRC world dictionary of medicinal and poisonous plants: common names, scientific names, eponyms, synonyms and etymology. CRC Press. 2012;5

2. University of Ghana. Herbarium samples. 2017.

3. Irvine FR. Woody plants of Ghana. 1961

4. Kakooko AB, Kerwagi SA. Medicinal plants in Uganda. InFirst National Plant Genetic Resources Workshop: Conservation and Utilization. Uganda. 1996

5. Geissler PW, Harris SA, Prince RJ, Olsen A, Achieng'Odhiambo R, Oketch- Rabah $\mathrm{H}$, et al. Medicinal plants used by Luo mothers and children in Bondo district, Kenya. J Ethnopharmacol. 2002;83(1-2):39-54.

6. Joseph CC, Hosea KM, Kisangau DP, Lyaruu HV. Use of Traditional Medicines in the Management of HIV/AIDS Opportunistic Infections in Tanzania. 2007.

7. Hedberg I, Hedberg O, Madati PJ, Mshigeni KE, Mshiu E, Samuelsson G. Inventory of plants used in traditional medicine in Tanzania. Plants of the families Acanthaceae-Cucurbitaceae. J Ethnopharmacol. 1982;6(1):29-60.

8. Baldascini A. Income generating opportunities arising from natural ecosystems in Uganda. International Food Policy Research Institute, Washington DC, USA 2002

9. Choudhary M, Kumar V, Malhotra H, Singh S. Medicinal plants with potential anti-arthritic activity. Journal of Intercultural Ethnopharmacology. 2015;4(2):147.

10. Danquah CA, Woode E, Boakye-Gyasi E. Anti-arthritic effects of an ethanolic extract of Capparis erythrocarpos isert roots in Freund's adjuvant-induced arthritis in rats. J Pharmacol Toxicol. 2011;6(3):201-17.

11. Martey O, Armah G, Sittie A, Okine L. A chronic toxicity study of the ground root bark of Capparis erythrocarpus (Cappareceae) in male Sprague-Dawley rats. PJBS 2013;23(16):1706-13.

12. Ghana News Agency. Ghana pioneering and leading the bitters brand: Ghana Trade News. 2017. [updated 18/10/2017. Available from: http://ghanatrade.com gh/Trade-News/ghana-pioneering-and-leading-the-bitters-brand.htm.

13. Mishra S, Tomar P, Lakra N. Medicinal and food value of Capparis-a harsh terrain plant. 2007.

14. Evans WC. Trease and Evans' Pharmacognosy E-Book, Saunders WB, Elsevier Health Sciences, $15^{\text {th }}$ ed. 2009;513-7.

15. Khandelwal KR. Practical pharmacognosy. Pragati Books Pvt. Ltd. 2008. 
16. Brain KR, Turner TD. The practical evaluation of phytopharmaceuticals. Bristol: Wright-Scientechnica. 1975.

17. Sini KR, Sinha BN, Rajasekaran A. Pharmacognostic evaluation on the Leaves of Capparis Zeylanica. Linn. Journal of Pharmacy Research 2011;4(5):1372-3.

18. Pearson M, Davies W, Mansfield T. Asymmetric responses of adaxial and abaxial stomata to elevated CO2: impacts on the control of gas exchange by leaves. Plant, Cell and Environment 1995;18(8):837-43.

19. Parkhurst DF. Diffusion of $\mathrm{CO}_{2}$ and other gases inside leaves. New Phytologist 1994;126(3):449-79.

20. Parkhurst DF, Wong SC, Farquhar GD, Cowan IR. Gradients of intercellular $\mathrm{CO}_{2}$ levels across the leaf mesophyll. Plant Physiology. 1988;86(4):1032-7.

21. Mott KA, Gibson AC, O'leary JW. The adaptive significance of amphistomatic leaves. Plant, Cell and Environment. 1982;5(6):455-60.

22. Peat $\mathrm{H}$, Fitter A. A comparative study of the distribution and density of stomata in the British flora. Biological Journal of the Linnean Society. 1994;52(4):377-93.

23. Rhizopoulou S, Psaras GK. Development and Structure of Drought-tolerant Leaves of the Mediterranean Shrub Capparis spinosa L. Annals of Botany. 2003;92(3):377-83

24. Kalidass C, Mohan VR, Abragam A. Pharmacognostic studies on Capparis sepi- aria. Pharmacognosy Journal. 2009;1(2):121

25. Brandizzi F, Ruzin SE. Plant microtechnique and microscopy. Oxford University Press 1999, No longer published by Elsevier. 2000;322.

26. Fahn A, Cutler D. Xerophytes. Encyclopedia of plant anatomy. 1992;13.

27. Aguoru C, Ahemen A, Olasan J. Comparative Micromorphological Studies on Two Landolphia Species in North Central Nigeria. Journal of Emerging Trends in Engineering and Applied Sciences. 2015;6(3):152-5.

28. Dziedzic S, Kearsley M. Handbook of starch hydrolysis products and thei derivatives. Springer Science and Business Media. 2012

29. Amponsah IK, Mensah AY, Ampofo EK, Bekoe SO, Sarpong FM, Jibira Y. Phar macognostic studies of the leaves and seeds of Cassia occidentalis (Linn.) (Leguminosae). Journal of Pharmacognosy and Phytochemistry. 2016;5(3):250.

30. Petchimuthu K, John DBA, Saravana GA, Leon SRT. Preliminary Phytochemical And Pharmacognostical Evaluation Of Capparis Separia L. 2010;1:522-6.

31. Satyanarayana T, Anjana A, Vijetha P. Plant Review Phytochemical and Pharmacological Review of Some Indian Capparis Species. Pharmacognosy Reviews 2008:2(4):36-45

\section{GRAPHICAL ABSTRACT}
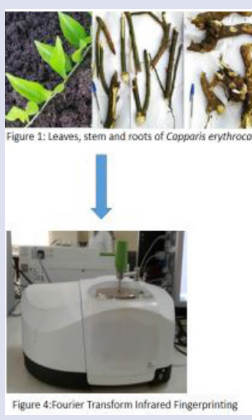

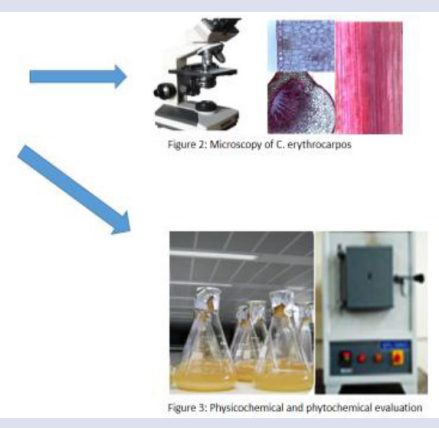

\section{SUMMARY}

- Capparis erythrocarpos commonly referred to as capers is used across Africa and several Ayurvedic systems in treating inflammatory conditions such as pain and arthritis. Though the caper plant is widely used, there are no standards to aid in its identification and consequent standardization. This paper established pharmacognostic characters of the leaves, stem and roots of capers focusing on macromorphological, micromorphological, physicochemical, phytochemical and fluorescence parameters. Fingerprints of powdered capers were also generated. This study has laid down pharmacognostic features for unequivocal standardization and consequent quality control of the leaves, stem and roots of capers.

\section{ABOUT AUTHORS}

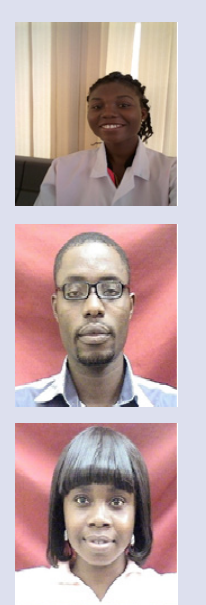

Twumasi Mary A, MPhil, Department of Pharmacognosy, Faculty of Pharmacy and Pharmaceutical Sciences, Kwame Nkrumah University of Science and Technology, Kumasi, Ghana

Ekuadzi Edmund, PhD, Department of Pharmacognosy, Faculty of Pharmacy and Pharmaceutical Sciences, Kwame Nkrumah University of Science and Technology, Kumasi, Ghana

Mante Priscilla K., PhD, Department of Pharmacology, Faculty of Pharmacy and Pharmaceutical Sciences, Kwame Nkrumah University of Science and Technology, Kumasi, Ghana.

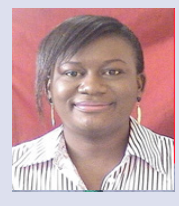

Boakye-Gyasi Mariam E., PhD, Department of Pharmaceutics, Faculty of Pharmacy and Pharmaceutical Sciences, Kwame Nkrumah University of Science and Technology, Kumasi, Ghana 


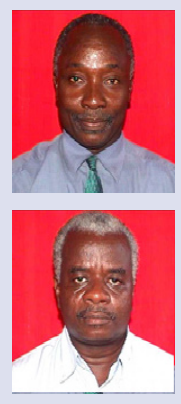

Mensah Merlin L.K., PhD, Department of Herbal Medicine, Faculty of Pharmacy and Pharmaceutical Sciences, Kwame Nkrumah University of Science and Technology, Kumasi, Ghana

Woode Eric, PhD, Department of Pharmacognosy, Faculty of Pharmacy and Pharmaceutical Sciences, Kwame Nkrumah University of Science and Technology, Kumasi, Ghana ewoode.

Cite this article: Mary TA, Edmund E, Priscilla MK, Mariam BE, Merlin MLK, Eric W. Pharmacognostic Studies of the Leaves, Stem and Root of Capparis erythrocarpos Isert (Capparaceae). Pharmacog J. 2019;11(1):112-8. 